\title{
Doctoral Dissertation Topics in Education: Do They Align with Critical Issues?
}

\author{
Roberta K. Weber and Ethan J. Allen \\ Florida Atlantic University, Jupiter, Florida, USA
}

\author{
rweber@fau.edu; eallen@fau.edu
}

\begin{abstract}
American society faces complex educational issues which impact many facets of its national interests. Institutions of higher education are granting doctoral degrees to educational leaders, but it is not known to what extent their dissertation topics are aligned with both longstanding and critical issues in education. Using a theoretical framework synthesizing Paul and Elder's critical thinking model and Kuhlthau's information seeking process, this study examines a set of education doctoral dissertation topical selections and categorizes them by general themes in relationship to many of the recognized educational issues in the United States.

Investigators categorized dissertations from four departments within the College of Education of their home institution. The dataset, retrieved from ProQuest Dissertations and Theses Global, consisted of 231 documents published between 2005 and 2014. Through an inter-rater process examining dissertation titles, abstracts, and keywords, the dissertations were assigned critical issue themes culled from nine editions of a college text, and then categorized under a broader topical scheme situated within a well-used educational research website. Findings indicated that most dissertations concentrated in studies that researched problems and issues within schools. Further, some of the issues considered longstanding were not studied by dissertation authors within the sample. For example, privatization of schools and classroom discipline and justice were not selected for study. Findings also suggest new directions for those responsible for dissertation supervision and topic selection. The study adds to the literature on dissertation topic selection that addresses existing educational issues.
\end{abstract}

Keywords: dissertation topics, $\mathrm{EdD}$ and $\mathrm{PhD}$ dissertations, critical issues in education, doctoral supervision, selection of dissertation topics

\section{Introduction}

Most educators might believe that many of today's educational issues are complex, persistent, and not easily solved. Doctoral students as future leaders in their chosen specializations have the

(CC BY-NC 4.0) This article is licensed to you under a Creative Commons AttributionNonCommercial 4.0 International License. When you copy and redistribute this paper in full or in part, you need to provide proper attribution to it to ensure that others can later locate this work (and to ensure that others do not accuse you of plagiarism). You may (and we encourage you to) adapt, remix, transform, and build upon the material for any non-commercial purposes. This license does not permit you to use this material for commercial purposes. potential to effect significant change within educational policy, educational culture, and their societies in general. The dissertation process itself provides practice in advanced research and communication, which not only benefits the student, but may also have direct social impact. Therefore the choice of dissertation topic matters, particularly if the research topic is of critical educational importance. What was unknown as this study began was whether or not dissertation topics in education- 
al fields were aligned with the pressing educational issues and problems in American society. Critical issues have sparked controversy, debate, and policy implementation over long periods of time without having been solved to the satisfaction of all.

Extensive searching for a comprehensive listing of the most important educational problems facing the American educational system will lead to a dead end, as no such list appears to exist. The searching of college textbooks and serial publications such as Improving Schools, Education Next, Current Issues in Education, and the International Journal of Educational Reform yields coverage of issues and problems singly, and each within its own context. A glance at the special interest group areas of the American Educational Research Association also points to the same pattern.

The range of issues themselves is wide. Studies on the problems of mainstreaming students with special needs into regular classrooms (Gottfried, Egalite, \& Kirksey, 2016) or how best to accommodate non-native speakers of English to become proficient readers and successful students (Coady, Harper, \& de Jong, 2015) are examples. It appears that the number of educational issues has not been tabulated collectively, nor do the issues seem to be quantifiable given the multiplicity of sub-issues which derive from them. Consequently, in the absence of an authoritative list of these issues, the first goal of this study was to create a list of some of the more widely published educational issues located within the available literature to provide a foundation for this inquiry. Secondary aims were to describe how a discrete set of doctoral dissertation topics, chosen by students at one of Florida's doctoral degree-granting institutions between 2005 and 2014, aligned with the listed issues and to categorize them in broader topical areas.

The focused literature search found that few studies explore the selection of dissertation topics and even fewer study educational dissertation topics exclusively. An early study by Isaac, Koenigsknecht, Malaney, and Karras (1989) surveyed 438 doctoral level students and faculty, some of whom came from education programs. The purpose of the study was to learn what the experience of university graduate students was with respect to their journey toward degree completion, i.e., research method, influences on topic selection, funding, facilities, and relationships with dissertation committees. The authors identified four common characteristics influencing choice of dissertation topics: adviser's preference, likelihood of publication, effect on job prospects, and trends in the field. Twenty-three years later Luse, Mennecke, and Townsend (2012) followed up on the review of Stoilescu and McDougall's manuscript (2010) on the publication process for newcomers to academe, but little was conveyed on what ought to be considered when choosing a research topic. A more current, but small sample size $(n=18)$ educational leadership study by Olalere, De Iulio, Aldarbag, and Erdner (2014) identified five factors influencing topical choices that included faculty member's research agenda, departmental core courses, professional experiences, life experiences, and practical experiences.

Luse and colleagues (2012) described their framework for selecting a topic based upon their review of literature from the 1960s and 1970s and introduced seven points that prepare students to think more deeply about the process and to adjust the mindset: Brainstorming, Outside the Discipline, Partner, Ask "Why", Talk about It, Drawing Is Fun and Effective, and lastly, Think of Things You Are Interested in (p. 144-145). These are all of interest and describe the more affective reasoning behind the dissertation topic selection, but do not lead the researcher to identify important problems that need to be solved to make long and short term recommendations that may change the educational system and improve the success rate of all learners.

Two studies investigated educational and school psychology issues. Lei (2009) focused on the process of topic selection and pointed to how the ideal topical choice takes advantage of faculty, personal interests, consideration of the nature of a given topic, its potential for future relevance, having a manageable research question completion timeframe, adequate funding, and whether or 
not a future audience will find it interesting. Topics were studied by Lewka and Ysselyke in 2010 that were gleaned from 1,119 doctoral dissertations comparing their current survey with others to identify how topics, methods, research trends, and the social context had changed over time. Their study reviewed titles and abstracts from 73 doctoral granting programs noting a trend from 2000-2007 that single-subject designs are being favored over experimental designs, with more topical coverage of diversity, public policy, effective instruction, and intervention. In both of these psychology-based population studies, the results provided additional findings, but did not pinpoint the issues that were considered of major importance at the time.

A small sample of research on educational issues from the social sciences area has been identified in which "hot topics" are discussed by Lei (2009) and Segol (2014). Each provided a snapshot of educational issues that addressed current issues between 2000 and 2013 with practical advice, suggesting that caution be used in selecting those topics due to the complexity and difficulty that might surround the selection. Lei recommended choosing hot topics for impressing prospective employers while warning against the kind of topics which lead to theoretical or political controversies. The study by Useem in 1997 laid the foundation for the cautionary stance of Lei and Segol, being that students need to consider their future career opportunities when selecting their topic. Useem posited that "The dissertation is more than just an exercise to gain competence. It should be an active pursuit of new knowledge" (1997, 3 of 7). All three of these studies suggest that addressing the major topics in education is an essential factor in career progression, but they did not describe the relationship between the topic and its alignment with current and critical issues.

The scholarship highlighted above described in various ways how the selection of a dissertation topic is the result of a complex process. Numerous factors influence the final decisions students reach in order to conduct a study on an educational problem. Due to the fact that the reviewed literature did not make a connection between globally important topics and the selection of these for dissertation study, a gap was noted. Further, there is no authoritative list of long-standing issues within the literature that would help guide decisions to select one of these for intensive study. In order to investigate the alignment of dissertation topics to the critical educational issues, the following research questions were addressed:

1. What are some of the most persistent and critical educational issues in the United States from 2005-2014 that were identified in textbook and periodical literature?

2. Which critical issue topic areas have education dissertation researchers from a Florida College of Education selected between the years 2005 and 2014?

3. How do dissertation topics researched by doctoral students at this same college align with these issues, and how do the selected topics compare between the 2005-2009 and 2010 2014 data?

\section{Conceptual Framework}

Two conceptual models support this study's framework: critical thinking (CT) developed by Richard Paul and Linda Elder and the information seeking process (ISP) articulated by Carol Kuhlthau. Each of these models derives from a line of forerunners. The antecedents of Paul and Elder's critical thinking model may be traced to Socrates (Paul \& Elder, 2007) and through the centuries to more contemporary scholars such as Robert H. Ennis, Diane Halpern, Peter Facione, and others (Flores, Matkin, Burbach, Quinn, \& Harding, 2012). Critical thinking, according to

Paul and Elder, simply stated, is "the art of thinking about thinking in an intellectually disciplined manner" (Paul, 2005). Their CT framework consists of three areas: the elements of thought (reasoning), intellectual standards (to be applied to reasoning), and the intellectual traits that are the 
result of the former components. Paul and Elder describe the characteristics of a well-cultivated critical thinker as one who is able to:

raise vital questions and problems, formulating them clearly and precisely; gather and assess relevant information, using abstract ideas to interpret it effectively; come to wellreasoned conclusions and solutions, testing them against relevant criteria and standards; think open-mindedly with alternative systems of thought, recognizing and assessing, as need be, their assumptions, implications, and practical consequences, and communicate effectively with others in figuring out solutions to complex problems. (Paul \& Elder, 2009, p. 2)

These are guiding principles that provide the foundation for establishing the intellectual decision making process as elaborated by Kuhlthau.

Kuhlthau's ISP traces the physical, cognitive, and affective experience the information seeker undergoes when committed to an academic research project. While the orderly "bibliographic paradigm" for information exists, there is a gap between it and the information seeker's natural process for information use (Kuhlthau, 1991). Uncertainty and anxiety are byproducts of this gap, which find resolution in sense-making and ultimately sharing of information. The theoretical basis for the ISP is to be found in the work of George Kelly (1905-1967), who developed the model of construction of personal world views in phases of assimilated information. The personal construct theory (Kelly, 1963) was largely responsible for Kuhlthau's understanding of the cognitive and affective components of the ISP. Drawing from Nicholas J. Belkin, the information seeker's need is identified in terms of a problem which must be resolved through the acquisition of new information, while at the same time relying upon existing knowledge for making the new connections. The end result of this process is a defined problem and awareness of an information gap. Kuhlthau also incorporates Robert S. Taylor's work into the ISP model. Taylor distinguished four levels of information need: visceral, conscious, formalized, and compromised. The progression from stage-to-stage leads the information seeker to ultimate sense-making.

Following these constructivist influences, Kuhlthau articulated a holistic process through which information seekers resolve information needs. Each step of the process is a stage, i.e., initiation, topic selection, exploration, focus formulation, information collection, and presentation. For every stage there is a concomitant array of feelings, thoughts, physical actions, and tasks. The ISP model has gained acceptance within the fields of school library media, library and information science (Jonassen \& Association for Educational Communications and Technology, 2004), and academic librarianship, particularly in the area of reference and instruction. It has relevance in most instances where an information need can be satisfied through an interface with a bibliographic paradigm or information system.

As doctoral students advance through the critical thinking process, issues of educational concern may be brought into focus and, from this position, can progress into a formalized and empirical design format. The critical thinking and information seeking processes work synergistically as students recognize which dissertation topics they will ultimately select while recognizing and responding to their information gaps, from dissertation initiation to completion. These guiding principles provide the foundation for establishing the intellectual decision making process. The elements of each student researcher's life experience influence the final outcome, which is present in each phase of the process. Kulhthau's unique background in library science further illuminates the importance of librarian expertise to researcher success.

\section{Methods}

The two-fold purpose of this study was to compose an authoritative, comprehensive list of critical educational issues in the United States and to conduct a descriptive study of how doctoral disser- 
tation topics have been aligning with these issues. A qualitative content analysis method (Beck \& Manuel, 2008; Krippendorff, 2004) was used as the primary means to resolve the research questions. The study defined the parameters of its dataset as a non-random sample of educational doctoral dissertations having been published within a recent ten-year period. The research design utilized two coding schemes under which enduring textbook chapter themes and dissertation topics could be categorized in separate inter-rater coding sessions. Evidence was analyzed and interpreted through arithmetic summaries and observable comparisons between the recognized educational issues and dissertation topics selected by doctoral students.

\section{Materials}

The dataset of 231 College of Education doctoral dissertations was obtained through a search within ProQuest's Dissertations and Theses Global database. Advanced searching enabled limitation to the authors' home institution between the years 2005 and 2014. Dissertations were published under the direction of faculty from four departments: Educational Leadership \& Research Methodology, Teaching \& Learning, Exceptional Student Education, and Counselor Education. The non-random sample served the purpose of yielding evidence for analysis within two consecutive five-year periods.

Nine editions of Critical Issues in Education: Dialogues and Dialectics (1990-2012) authored by Nelson, Carlson, Palonsky, and McCarthy (Nelson, Palonsky, \& Carlson, 1990, 1992, 1996, 2000; Nelson, Palonsky, \& McCarthy, 2003, 2004, 2007, 2010, 2012) provided thematic content over its lengthy publication history. A particular reason for selecting this college text was that over time continuous revisions had been made and, more importantly, that the authors have taken a neutral approach to the controversial issues covered. The enduring themes found throughout most of the textbook editions (listed in Table 1) comprise the basis for one of the coding schemes for categorizing (Guest, MacQueen, \& Namey, 2012) the dissertation topics.

Table 1. Description of critical educational issues based upon nine editions of Critical Issues in Education: Dialogues and Dialectics (Nelson, Carlson, Palonsky \& McCarthy)

\begin{tabular}{ll}
\hline \multicolumn{1}{c}{ Issue } & \multicolumn{1}{c}{ Brief Description } \\
\hline Academic Achievement & Academic gap between whites and non-whites \\
\hline Academic Freedom & Instruction without unreasonable interference \\
\hline $\begin{array}{l}\text { Basic Education } \\
\text { Corporations, Commerce, and } \\
\text { School }\end{array}$ & Traditional philosophy and testing/evaluation \\
\hline Curriculum Control & Link between employment and education \\
\hline Discipline and Justice & Course inclusion for skills and knowledge \\
\hline Financing Schools & Restorative justice and conflict resolution \\
\hline Gender Equity & Centralized (federal) or decentralized (local) funding \\
\hline Inclusion and Mainstreaming & Title IX Act to ban discrimination by sex \\
\hline Instructional Leadership & Supporting students with special needs \\
\hline Multicultural Education & Teacher empowerment as leaders \\
\hline Privatization of Schools & All students have equal chances of success \\
\hline Reading & Private funding for PK-12 schools \\
\hline Religion and Public Schools & Language arts teaching strategies and methods \\
\hline School Choice & Separation of church and state \\
\hline School Leadership & Parental choice and voucher distribution \\
\hline
\end{tabular}




\begin{tabular}{ll}
\hline \multicolumn{1}{c}{ Issue } & \multicolumn{1}{c}{ Brief Description } \\
\hline Standardized Testing & PK-12 evaluation accountability requirements \\
\hline Standards Based Reform & State and national movement PK-12 to raise standards \\
Teachers Unions & Collective bargaining and representation for teachers \\
Technology and Learning & Delivering instruction with appropriate technology \\
Values and Character Education & Teaching core ethical values \\
\hline Violence & Multifaceted physical/verbal negative impact on students \\
\hline
\end{tabular}

Education Next, published by the Hoover Institute at Stanford University, is an open access journal and website which publishes on a wide range of timely educational issues. The peer reviewed journal and web materials have been used heavily by students at the authors' institution in fulfillment of "U.S. Curricular Trends and Issues" course assignments (Allen \& Weber, 2014, 2015). The site features a topical search option, and organizes content within three broad topical categories: Government and Politics, Inside Schools, and School Policy (Education Next Topics, 2015). Table 2 presents the range of educational topics appropriate to each broad category, and provides the current study with a coding scheme for a broader categorization of dissertation topics.

Table 2. Education Next Categories and Associated Topics

\begin{tabular}{|c|c|c|}
\hline A) Government \& Politics & B) Inside Schools & C) School Policy \\
\hline Courts \& Law & Character Education & $\begin{array}{c}\text { Charter Schools \& } \\
\text { Vouchers }\end{array}$ \\
\hline $\begin{array}{c}\text { Governance \& Leader- } \\
\text { ship }\end{array}$ & Curriculum & International \\
\hline Media & Early Childhood \& Pre- \\
school & No Child Left Behind \\
\hline Public Opinion & Special Education & School Spending \\
\hline $\begin{array}{c}\text { State \& Federal } \\
\text { Unions \& Collective Bar- } \\
\text { gaining }\end{array}$ & Teachers \& Teaching & Standards \\
\hline
\end{tabular}

In Table 3, textbook themes and Education Next topical categories are juxtaposed for the purpose of associating the textbook themes with the journal's topics and categories, providing the investigators a usable rubric for coding each dissertation according to a single broad category: A, B, or C.

Two exceptions to the assignment of themes to broad categories were (1) to place Leadership within Inside Schools because numerous dissertations treated the roles of principals within their school environments, and (2) to place Curriculum Control within Government \& Politics since this is a national issue in the U.S. at present. 
Table 3. Conceptual Relationships between Textbook Chapter Themes and Topic Categories in Education Next

\begin{tabular}{|c|c|}
\hline $\begin{array}{l}\text { Categorized Topic Areas } \\
\text { from Education Next }\end{array}$ & $\begin{array}{l}\text { Recurring Textbook } \\
\text { Chapter Themes }\end{array}$ \\
\hline $\begin{array}{l}\text { Government \& Politics } \\
\text { (Category A) }\end{array}$ & \\
\hline $\begin{array}{l}\text { Courts and Law } \\
\text { Governance and Leadership } \\
\text { Media, Public Opinion } \\
\text { State and Federal } \\
\text { Unions and Collective Bargaining }\end{array}$ & $\begin{array}{l}\text { Curriculum Control } \\
\text { Corporations, Commerce, and School } \\
\text { Teachers Unions }\end{array}$ \\
\hline $\begin{array}{l}\text { Inside Schools } \\
\text { (Category B) }\end{array}$ & \\
\hline $\begin{array}{l}\text { Character Education } \\
\text { Curriculum } \\
\text { Early Childhood and Preschool } \\
\text { Special Education } \\
\text { Teachers and Teaching } \\
\text { Technology }\end{array}$ & $\begin{array}{l}\text { Values and Character Education } \\
\text { Religion and Public Schools } \\
\text { Violence } \\
\text { Discipline and Justice } \\
\text { Multicultural Education } \\
\text { Academic Achievement Gap } \\
\text { Instructional Leadership } \\
\text { Inclusion and Mainstreaming } \\
\text { Technology and Learning } \\
\text { School Leadership } \\
\text { Reading* } \\
\text { Basic Education* }\end{array}$ \\
\hline \multicolumn{2}{|l|}{$\begin{array}{l}\text { School Policy } \\
\text { (Category C) }\end{array}$} \\
\hline $\begin{array}{l}\text { International } \\
\text { No Child Left Behind } \\
\text { Charter Schools and Vouchers } \\
\text { School Spending } \\
\text { School Choice } \\
\text { Standards, Testing, and Accountability }\end{array}$ & $\begin{array}{l}\text { Academic Freedom } \\
\text { Gender Equity } \\
\text { Privatization of Schools } \\
\text { Financing Schools } \\
\text { School Choice } \\
\text { Standardized Testing } \\
\text { Standards Based Reform }\end{array}$ \\
\hline & $\begin{array}{l}\text { * Infrequently recurring chapter } \\
\text { themes }\end{array}$ \\
\hline
\end{tabular}




\section{Procedures}

A content analysis procedure was used to create a listing of the most critical and persistent educational issues the United States. The investigators compared tables of content from nine editions of a single textbook published steadily from 1990 through 2012 (Nelson, Palonsky, \& Carlson, 1990, 1992, 1996, 2000; Nelson, Palonsky, \& McCarthy, 2003, 2004, 2007, 2010, 2012). Twenty chapter titles that repeated consistently across these editions qualified for inclusion on the list of critical issue themes. Two infrequently recurring chapter titles located in three editions of the text (Nelson, Palonsky, \& Carlson, 1992; Nelson et al., 1996; Nelson, Palonsky, \& McCarthy, 2003), were added retroactively because they were found to be more appropriate matches to a notable number of dissertation topics, to be discussed below. The finalized list of twenty-two chapter themes served as a rubric for matching dissertation topics to critical issues.

The first of two inter-rater consensus estimates (Oakleaf, 2009; Stemler, 2004) was piloted by the investigators to determine whether independently scored (Creswell, 2014) dissertation topics, determined by student-provided keywords (ProQuest LibGuide for Dissertations and Theses, 2016), dissertation titles, and abstracts showed any similarity in the assignment of dissertations to the chapter theme rubric. The author-investigators, coming from differing academic backgrounds and professional experiences, have collaborated annually and share some common understandings of education's critical issues both from classroom and library instructional settings. There was a high level of agreement between these raters in the pilot $(92 \%)$. This was considered a sufficient level of agreement to continue independent scoring of the full dataset. It was discovered that certain dissertations did not fit neatly into the list of chapter themes, but were more relevant to chapter themes which were outliers. Consequently, the list of themes was expanded to accommodate two additional themes. In numerous cases, more than one chapter theme tag was assigned to a given dissertation entry, with rubric chapter themes applied in 273 instances. Reliability was controlled by providing brief descriptions of the chapter themes (Table 1).

A second inter-rater process was used to associate dissertation topics with broader critical issue topic areas. The organization through which Education Next publishers have placed topics under broad categories and the parallel conceptual relationships from the Critical Issues textbook (Table 3 ) served as the codebook for assigning dissertation themes to the broader categories of Government \& Politics (A), Inside Schools (B), and School Policy (C). The same raters piloted the categorization of dissertations into A, B, and C, and generally satisfied with the outcome, proceeded to code the full dataset. The consensus estimate was lower (90\%). The lower reliability measure may be attributable to ambiguity or subjectivity factors, given that the three categories were not tightly defined.

Content analysis of the alignment between dissertation topic and critical issues was expressed numerically within a table (Beck \& Manuel, 2008). The number of dissertations whose topic areas fell within the scope of a single critical issue chapter theme was tabulated for each year, summed for each consecutive five-year period, and tabulated in full for a ten-year period. Dominance of certain chapter themes and continuity or discontinuity of topics from year-to-year were to be extrapolated (Krippendorff, 2004) as indicators of high interest issues or possible trends, of varying duration. Instances in which no dissertations were written within the scope of a critical issue theme were noted.

\section{Results}

\section{The Persistent Issues}

This study emerged in response to questions concerning the alignment of a small set of $\mathrm{PhD}$ and EdD dissertation investigations to some of the more important educational issues experienced 
within a national context. Educational issues are not unique to one single region of the world, but are found globally, as evidenced by their commanding presence within the literature. However, narrowing to a single region, the investigators found it necessary to compile a list of the most important of national issues as the basis for identifying topical gaps within a Florida sample. Twenty-two critical educational issues of longstanding existence in the United States are listed in Table 1. Two issues, "Reading" and "Basic Education", were not initially part of the full tally of longstanding issues, but were incorporated due to their prevalence within the dataset of dissertation topics and their occurrence in three editions of the textbooks examined, (Nelson et al., 1992; Nelson et al., 1996; Nelson et al., 2003). The issues in the full list are longstanding in virtue of the fact that they have appeared consistently through nine editions of a college text, spanning a publication history of twenty-three years (Nelson, Palonsky, \& Carlson, 1990, 1992, 1996, 2000; Nelson, Palonsky, \& McCarthy, 2003, 2004, 2007, 2010, 2012). The researchers note that studies on these issues appear individually within the scholarly record, but that the literature is silent with respect to lists of issues. This is not to say that the present researchers have a comprehensive or complete listing, but rather that the list was constructed critically and served as a codebook for matching dissertation topic selections to this particular range of issues.

\section{Critical Issue Topic Areas}

The critical issue topic areas are represented by the broader categories utilized by the Education Next organizational scheme for topics: Government \& Politics, Inside Schools, and School Policy. Dissertations concentrated most heavily in Category B, Inside Schools, with 202 dissertation topics having been coded under this category. Category C, School Policy, had 26 dissertations assigned to it, while two dissertations were coded under Category A, Government \& Politics. Table 4 presents the distribution of categorized dissertations in relationship to the college department responsible for their origin.

Table 4. Distribution of dissertations by department and critical issue topic area

\begin{tabular}{|l|c|c|c|}
\hline College Department & $\begin{array}{c}\text { (A) Government \& Poli- } \\
\text { tics }\end{array}$ & $\begin{array}{c}\text { (B) Inside } \\
\text { Schools }\end{array}$ & $\begin{array}{c}\text { (C) School Poli- } \\
\text { cy }\end{array}$ \\
\hline $\begin{array}{l}\text { Educational Leadership } \\
\text { \& Research Methodology }\end{array}$ & 2 & & 19 \\
\hline Teaching \& Learning & & 126 & 7 \\
\hline $\begin{array}{l}\text { Exceptional Student Ed- } \\
\text { ucation }\end{array}$ & & 13 & \\
\hline & & & \\
\hline Counselor Education & & 15 & \\
\hline & & & \\
\hline Totals & 2 & 203 & 26 \\
\hline
\end{tabular}

Dissertations were authored under the supervision of faculty from four College of Education departments. Those supervised by faculty in Educational Leadership (Education Leadership and Research Methodology) numbered 147 (64\%). Teacher Education, (subsequently Teaching \& Learning, and Curriculum, Culture, \& Educational Inquiry), numbered 57, or 25\%. Exceptional Student Education and Counselor Education student authors produced 13 and 14 dissertations respectively, or approximately $6 \%$ of the dataset. 


\section{Dissertation Alignment with Critical Issues}

The alignment of dissertation topics with critical issue textbook chapter themes is presented in Table 5. The data reveal how the textbook themes and dissertation topics line up over a ten year period, in two five-year segments. The most frequently occurring chapter themes were Instructional Leadership $(n=76)$, Technology and Learning $(n=42)$, and School Leadership $(n=40)$. Six of the recurring chapter themes were not matched to dissertation topics due to an absence of related content within the dataset. These were Academic Freedom, Corporations, Commerce, \& Schools, Discipline \& Justice, Privatization of Schools, Religion \& Public Schools, and Teachers Unions. Two chapter themes from three editions of the Nelson et al. textbook, namely Reading $(n=24)$ and Basic Education $(n=9)$, were applied to 33 dissertations as the most appropriate matches to topical content.

The data in Table 5 were broken into two segments for the purpose of observing possible trends. It was noted that in comparing consecutive five-year periods, there was an increase in recent years of studies on: Basic Education, Gender Equity, Instructional Leadership, Multicultural Education, School Reform, Technology \& Learning, Values \& Character Education, and Violence. Topical issues that were studied with greater relative frequency in the earlier period were: Academic Achievement Gap, Curriculum Control, Inclusion \& Mainstreaming, Reading, School Leadership, Standardized Testing, and Standards-Based Reform. Topics which held steady over the ten-year period were Financing Schools and School Choice.

The listing of critical issues has provided a heretofore non-existent reference for mapping educational topics studied by doctoral students since the recent turn of the century. The distribution of topics within the three main categories showed strongest interest of 203 studies from the Inside of Schools topical area in contrast with only two researching Government and Political themed areas. The findings also contributed a review of the trends under investigation within a ten year period. 


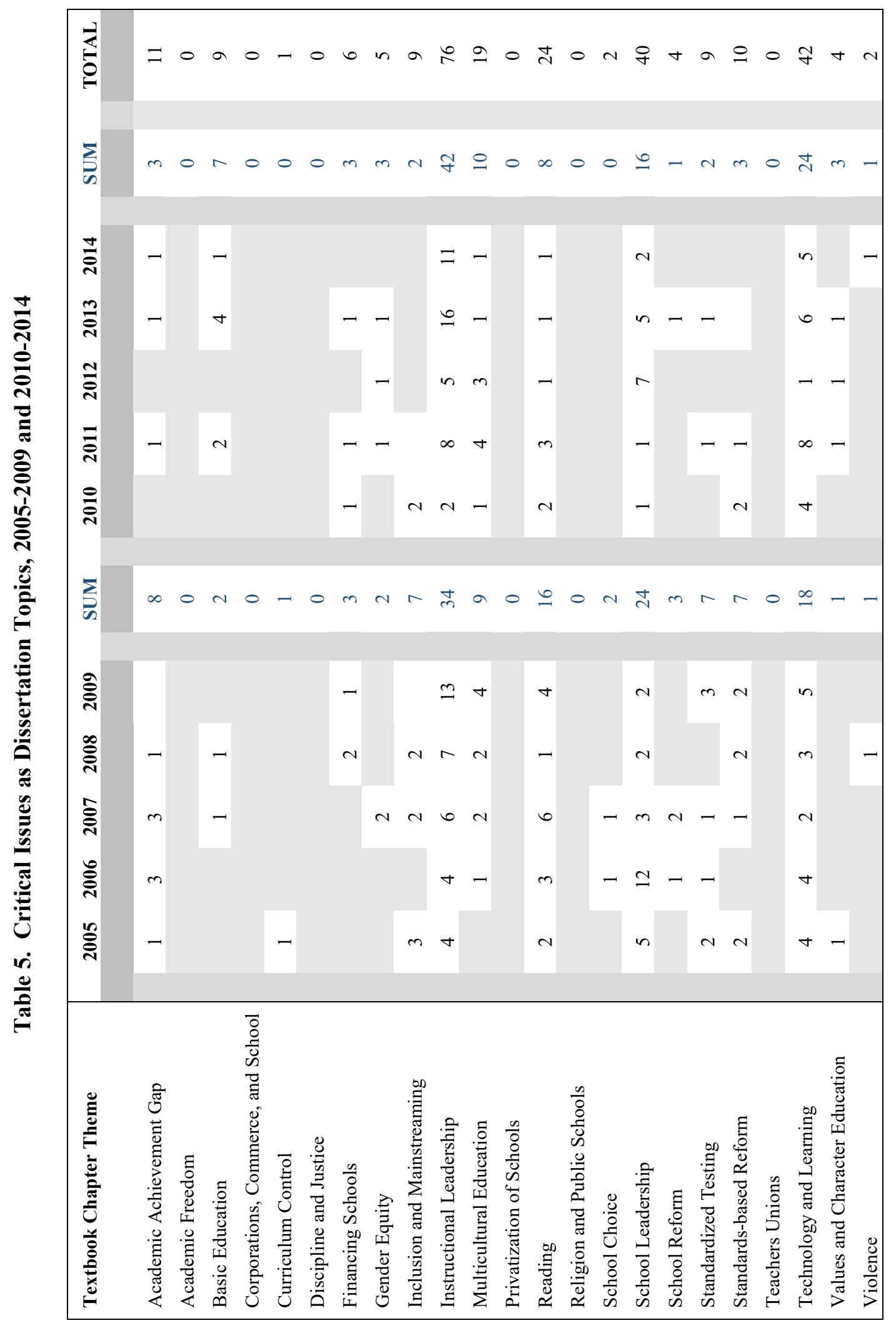




\section{Discussion}

Identifying both the perennial issues and the most current, pressing needs across educational disciplines is an essential part of what ought to be addressed by scholars in a timely manner. Doctoral dissertations published from colleges and schools of education across the USA produce many recommendations. These outputs support or challenge previous empirical findings which are most often based upon individual and societal needs. Each year the backlog of critical issues grows while a concentration of research is diminished in core areas such as reading, inclusion, and mainstreaming. "Hot topics" are no longer at the forefront of student selection given that peer reviewed studies suffer notable publication time lags.

The overall complexity of the doctoral research topic selection process has been described in previous investigations, yet none so far have identified the connection to the persistent critical educational issues in the United States. References were found which covered "hot topics", meaning those which were timely or controversial, but none to-date has attempted to describe an alignment of selected topics to a defined range of critical issues. The findings of this study pointed to a disproportionate interest by students to study topics related to the school environment (Ali, Watson, \& Dhingra, 2016; Lei, 2009; Luse, 2012; Segol, 2014; Useem, 1997). The authors speculate that topics pertaining to government and policy or school policy would more likely be taken up by dissertation authors whose interests are more philosophical or theoretical than action-research oriented.

With respect to trends, the findings show continuous, steady interest in financing schools and school choice. These topic areas are subject to the vicissitudes of public funding and public opinion, but it is understandable that these topics have an enduring presence among education dissertations and are less susceptible to trending. What is a surprising finding is that six of the listed critical issues have no presence within the dataset: academic freedom, corporations, commerce and schools, discipline and justice, privatization of schools, religion and public schools, and teachers unions. Here it would be valuable to have data to compare findings with similar institutions. The upward trends and downward trends of the remaining issues cannot be explained within the scope of this study, but are likely attributable to personal interest or supervisory direction as described in the literature cited above.

\section{Conclusion}

This study examined 231 doctoral education dissertation topics and their relationship to a set of 22 recognized critical issues in American education. Further, the investigators clustered the dissertation topics into three broader categories of educational importance, "Inside Schools," "Government \& Politics," and "School Policy". This categorizing was necessary and beneficial in order for the coding process and analysis to address the educational focus of the three research questions. Certain limitations of this study are noted. First, the study was conducted using the authors' home institution's archival data taken directly from a conventional library search. Second, there is no comprehensive list known to the authors that identifies or describes every critical educational issue in the United States. This finding was perplexing during the initial exploration of the topic, but provided the foundation for the qualitative investigation to begin.

Looking at the trend of topic selection over the ten year period had greatest representation of the issues and problems surrounding instructional leadership, technology and learning, and school leadership. There were no dissertations which covered six critical issue topics. It is questionable why those six topic areas were not the focus of any study producing solutions to the particular problems associated with the topic. 
It has been documented in the literature that dissertation supervisors can be rather influential when the doctoral student is selecting a dissertation topic. Therefore it may be of benefit to the research community to look beyond some of the more personal topic choices in order to find answers to the important and long-standing problems in education in a timely manner and within the current societal expectations. While this study addressed topics from several educational specializations, it may have similar application to other fields of study.

To further explore doctoral dissertations treating educational issues, an examination of problem statements and their corresponding solutions would be a natural progression of the current study, since it would inform the scholarly community of how doctoral students believe educational issues might be solved. Topical selection and narrow focus are the results of a complex process, and the information searching process is more than a cognitive function, which also involves the emotions and physical activity. Critical thinking and critical thinking dispositions, however, remain the common denominator for all types of dissertation topical choice. The findings of this study suggest that students might be encouraged to ask themselves two questions: (1) whether the research problem under consideration affects a large or small number of people and (2), where does the selected topic fall along a continuum between personal concerns and important, critical issues.

\section{Acknowledgement}

The authors would like to recognize the diligent efforts of Mr. Paul Probst and Mr. Peter Bui in the data collection phase of this study.

\section{References}

Ali, P. A., Watson, R., \& Dhingra, K. (2016). Postgraduate research students' and their supervisors' attitudes towards supervision. International Journal of Doctoral Studies, 11, 227-241. Retrieved from http://www.informingscience.org/Publications/3541

Allen, E. J., \& Weber, R. K. (2014). The library and the web: Graduate students' selection of open access journals for empirical literature searches. Journal of Web Librarianship, 8(3), 243-262. doi:10.1080/19322909.2014.927745

Allen, E. J., \& Weber, R. K. (2015). An exploration of indexed and non-indexed open access journals: Identifying metadata coding variations. Journal of Web Librarianship, 9(2), 65-84. doi:10.1080/19322909.2015.1020185

Beck, S. E., \& Manuel, K. (2008). Practical research methods for librarians and information professionals. New York: Neal-Schuman Publishers.

Coady, M. R., Harper, C., \& de Jong, E. J. (2015). Aiming for equity: Preparing mainstream teachers for inclusion or inclusive classrooms? TESOL Quarterly, 50(2), 340-368. doi:10.1002/tesq.223

Creswell, J. W. (2014). Research design: Qualitative, quantitative, and mixed methods approaches. Thousand Oaks, California: SAGE Publications.

Education Next Topics. (2015, August 21). Retrieved from http://educationnext.org/topics/

Flores, K. L., Matkin, G. S., Burbach, M. E., Quinn, C. E., \& Harding, H. (2012). Deficient critical thinking skills among college graduates: Implications for leadership. Educational Philosophy and Theory, 44(2), 212-230. doi:10.1111/j.1469-5812.2010.00672.x

Gottfried, M. A., Egalite, A., \& Kirksey, J. J. (2016). Does the presence of a classmate with emotional/behavioral disabilities link to other students' absences in kindergarten? Early Childhood Research Quarterly, 36, 506-520. doi:10.1016/j.ecresq.2016.02.002

Guest, G., MacQueen, K. M., \& Namey, E. E. (2012). Themes and codes. In G. Guest, K. M. MacQueen, \&E. E. Namey, Applied thematic analysis (pp. 49-78). doi:10.4135/9781483384436 
Isaac, P., Koenigsknecht, R., Malaney, G., \& Karras, J. (1989). Factors related to doctoral dissertation topic selection. Research in Higher Education, 30(4), 357-373. doi:10.1007/BF00992560

Jonassen, D. H., \& Association for Educational Communications and Technology. (2004). Handbook of research on educational communications and technology. Mahwah, N.J: Lawrence Erlbaum.

Kelly, G. (1963). A theory of personality: The psychology of personal constructs. New York: W.W. Norton.

Krippendorff, K. (2004). Content analysis: An introduction to its methodology. Thousand Oaks, CA: Sage.

Kuhlthau, C. (1991). Inside the search process: Information seeking from the user's perspective. Journal of the American Society for Information Science, 42(5), 361-371. doi:10.1002/(SICI)10974571(199106)42:5

Lei, S. A. (2009). Strategies for finding and selecting an ideal thesis or dissertation topic: A review of literature. College Student Journal, 43(4), 1324.

Lewka, A., \& Ysseldyke, J. (2010). Dissertation research in school psychology: Changes in topics and methodology over the past 25 years. Journal of Applied School Psychology. 26(1), 17- 37. doi:10.1080/15377900903386047

Luse, A., Mennecke, B., \& Townsend, A. (2012). Selecting a research topic: A framework for doctoral students. International Journal of Doctoral Studies 7, 143-151. Retrieved from https://www.informingscience.org/Publications/1572

Nelson, J. L., Palonsky, S. B., \& Carlson, K. (1990). Critical issues in education: Dialogues and dialectics (1st ed.). Boston: McGraw-Hill.

Nelson, J. L., Palonsky, S. B., \& Carlson, K. (1992). Critical issues in education: Dialogues and dialectics (2nd ed.). Boston: McGraw-Hill.

Nelson, J. L., Palonsky, S. B., \& Carlson, K. (1996). Critical issues in education: Dialogues and dialectics (3rd ed.). Boston: McGraw-Hill.

Nelson, J. L., Palonsky, S. B., \& Carlson, K. (2000). Critical issues in education: Dialogues and dialectics (4th ed.). Boston: McGraw-Hill.

Nelson, J. L., Palonsky, S. B., \& McCarthy, M. R. (2003). Critical issues in education: Dialogues and dialectics with PowerWeb Card. Boston: McGraw-Hill.

Nelson, J. L., Palonsky, S. B., \& McCarthy, M. R. (2004). Critical issues in education: Dialogues and dialectics (5th ed.). Boston: McGraw-Hill.

Nelson, J. L., Palonsky, S. B., \& McCarthy, M. R. (2007). Critical issues in education: Dialogues and dialectics (6th ed.). Boston: McGraw-Hill.

Nelson, J. L., Palonsky, S. B., \& McCarthy, M. R. (2010). Critical issues in education: Dialogues and dialectics (7th ed.). Boston: McGraw-Hill.

Nelson, J. L., Palonsky, S. B., \& McCarthy, M. R. (2012). Critical issues in education: Dialogues and dialectics (8th ed.). Boston: McGraw-Hill.

Oakleaf, M. (2009). Using rubrics to assess information literacy: An examination of methodology and interrater reliability. Journal of the American Society for Information Science and Technology, 60(5), 969-983. doi:10.1002/asi.21030

Olalere, A. A., De Iulio, E., Aldarbag, A. M., \& Erdener, M. A. (2014). The dissertation topic selection of doctoral students using dynamic network analysis. International Journal of Doctoral Studies, 9, 85107. Retrieved from https://www.informingscience.org/Publications/2031

ProQuest Dissertations \& Theses (PQDT): Searchable Fields. (2016, May 19). Retrieved from http://proquest.libguides.com/pqdt/fields 
Paul, R. (2005). The state of critical thinking today. New Directions for Community Colleges, 2005(130), 27-38. doi:10.1002/cc.193

Paul, R., \& Elder, L. (2007). Critical thinking: The art of Socratic questioning. Journal of Developmental Education, 31(1), 36-37.

Paul, R., \& Elder, L. (2009). The miniature guide to critical thinking: Concepts \& tools. Dillon Beach, CA: Foundations for Critical Thinking Press.

Segol, G. (2014). Choosing a dissertation topic: Additional pointers. College Student Journal 48(1), 108.

Stemler, S.E. (2004). A comparison of consensus, consistency, and measurement approaches to estimating interrater reliability. Practical Assessment, Research \& Evaluation, 9(4). Retrieved from http://PAREonline.net/getvn.asp?v=9\&n=4

Stoilescu, D., \& McDougall, D. (2010). Starting to publish academic research as a doctoral student. International Journal of Doctoral Studies, 5, 79-92. Retrieved from https://www.informingscience.org/Publications/1333

Useem, B. (1997). Choosing a dissertation topic. PS: Political Science \& Politics, 30(2), 231-216.

\section{Biographies}

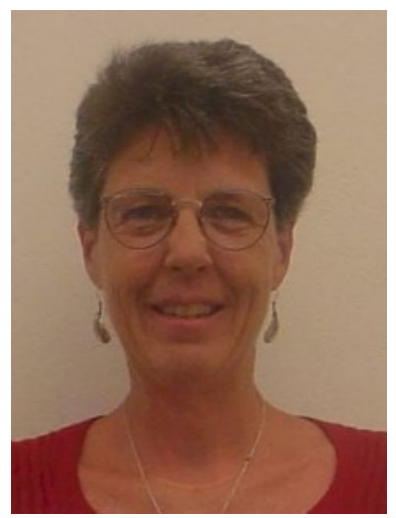

Roberta K. Weber has been teaching in higher education for 25 years with a specialization in instructional design and technology integration. Her current appointment in the Department of Curriculum, Culture, and Educational Inquiry at Florida Atlantic University focuses on graduate education and providing guidance to doctoral research students as they complete their studies. She has engaged her students in study abroad opportunities for the last 15 years at FAU and is the Founder of AUCEi, an international learned society.

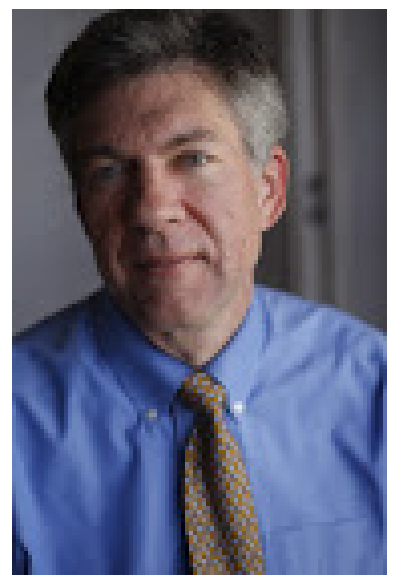

Ethan J. Allen is the director of the John D. MacArthur campus library at Florida Atlantic University in Jupiter, FL. In addition to his work in library management, he has served as president of the Palm Beach County Library Association. For the last twenty years, he has been offering voluntary assistance to several institutions in the areas of collection management and archival services locally in Florida, and in Norcia, Italy. His research interests focus on information seeking behaviors of graduate and doctoral students. 